\title{
混合砂河床における網状流路の数值解析 NUMERICAL ANALYSIS OF BRAIDED STREAMS FORMED ON BEDS WITH NON-UNIFORM SEDIMENT
}

\author{
竹林 洋史 ${ }^{1} \cdot$ 江頭 准治 $^{2} \cdot$ 岡部 健士 ${ }^{3}$ \\ Hiroshi TAKEBAYASHI, Shinji EGASHIRA and Takeshi OKABE \\ ${ }^{1}$ 正会員 博士 (工学) 徳島大学助手 . 学部建設工学科 (テ770-8502 徳島市南常三島町 2-1) \\ ${ }^{2}$ 正会員 工博 立命館大学教授 理工学部土木工学科（テ525-8577 滋賀県草津市野路東 1-1-1） \\ ${ }^{3}$ 正会員 工博 徳島大学教授 工学部建設工学科（干770-8502 徳島市南常三島町 2-1）
}

\begin{abstract}
Dynamic characteristics of braided streams formed on beds with non-uniform sediment are discussed by means of numerical analysis. Results are summarized as follows. (1) Sedime nt particles are exchanged to fine ones in dry bed regions and coarse in streams, respectively, under steady flow conditions, whereas, under unsteady flow conditions, mean diameter in trough increases in the rising stage of water discharge and decreases in the falling stage. (2) If the frequency with which water covers bars decreases by reducing peak flood discharge, vegetation growth will be promoted. Furthermore, vegetation suppresses the development of small streams and grows large streams. (3) If huge amount of sediment is excavated artificially, number of streams will decrease with eroding bed in main streams.
\end{abstract}

Key words: braided streams, non-uniform sediment, numerical analysis, vegetation, seepage flow

\section{1. はじめに}

多様な生態系の保存・創生を目標とした河川の整 備計画を作成する上で最も難しい問題が，目標とす る河川像を描くことかと思われる。従来, 多様な生 態系を有する河川像として, 過去の人為的インパク トの少ない時期の河川を設定し, 河川整備計画を考 えることが多い。しかし, 土地利用形態が以前と異 なる上に, ダム貯水池や砂防ダムなど水と土砂の流 出特性をコントロールする河川構造物は既に建設 され，市民の生活に不可欠なものとなっており，過 去の人為的インパクトの少ない時期と同じような 水と土砂の流出過程を復活させるのは困難である. さらに, 過去の人為的インパクトの少ない時期の水 辺空間は, 非平衡系の地形形成プロセスのある一時 期の水辺空間に過ぎず, それ以上に多様な物理環境 を有する水辺空間が存在すると考えられる.では， どのような河川地形が生態系に対して多様な物理 環境を提供できるのであろうか? 非粘着性河床材 料により形成された沖積河川については, 網状流路 がその一つの答えのように思われる.

従来の網状流路の形成機構に関する研究は, 現象
の複雑さのため, 現地調査 ${ }^{1}$, 2)や水路実験による検

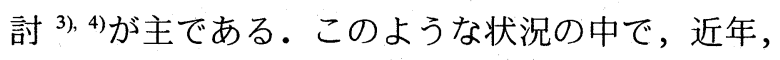
数值解析により流路を再現しようとする試みもな されている ${ }^{5), 60,7), 8)}$. 著者らは9 ${ }^{9)}$, これまで非粘着性 河床材料の一様砂を対象にして, 直線河道に形成さ れる網状流路の時空間的変動特性を明らかにして きた.それによると，川幅・水深比が大きい水理条 件では, 河道内に様々なスケールの浮州と流路が形 成され，多様な水辺空間が形成される. しかし，こ れらの数值解析による研究は, 河床材料を一様砂と して取り扱っており, 混合砂河床の網状流路の動態 を明らかにするに至っていない。混合砂河床では， 砂碟の分級現象が発生し，流砂量の時空間的な分布 が一様砂の場合と異なるため, 砂州の形状が一様砂 河床の場合とは異なる ${ }^{10)}$.

一方, 日本の多くの河川では, 近年, 砂州の固定 化が発生するとともに流路の本数が減少している 11). 砂州の固定化は, 河道内で最も動植物の生産量 が大きい陸水の遷移域を減少させるとともに, 砂州 域が陸域の動植物の生息空間となるため, 水辺の物 理環境が単調化する. このような, 砂州の固定化及 び流路本数の減少は, 夕゙ム貯水池による洪水調節と 
ともに, 河床掘削及び上流からの供給土砂の減少に よる流路内の河床位の低下及び河床材料の粗粒化 の影響も大きいと考えられる.これらの現象のメカ ニズムを明らかにするには，河床材料の混合粒径と しての取り扱いが不可欠と考えられる.

このような観点に基づき, 本論文では, 数值解析 により, 混合砂河床の網状流路の動態及び河床材料 の粒度の空間分布特性を明らかにするとともに，砂 州の固定化及び流路本数の減少機構を検討する.

\section{2. 解析方法}

河道内に流路が形成されると，計算領域に表面流 の無い浮州が形成される. 本解析では, 表面流と浸 透流の両方を計算し, 浮州域の土中の流れの解析も 行う. 表面流の計算には, 水深平均された平面二次 元流れの支配方程式を用いる ${ }^{12)}$. ただし，以下のよ うに，質量保存則にのみ浸透流による流入・流出を 考慮し, 浸透流による運動量の流入・流出は考慮し ていない. また，浸透流は平面二次元の飽和流れと して取り扱う。

$\Lambda \frac{\partial z}{\partial t}+\frac{\partial}{\partial x}(u h)+\frac{\partial}{\partial y}(v h)+\frac{\partial}{\partial x}\left(u_{g} h_{g}\right)+\frac{\partial}{\partial y}\left(v_{g} h_{g}\right)=0$

ここに, $t$ は時間, $x$ 及び $y$ は流下方向及び横断方向 の座標, $h$ は表面流の水深, $h_{g}$ は浸透流の水深, $u$ 及び $v$ は流下方向及び横断方向の表面流の流速, $u_{g}$ 及び $v_{g}$ は流下方向及び横断方向の浸透流の流速, $z$

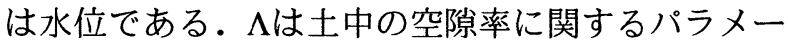
夕であり, $z \geqq z_{b}$ で $\Lambda=1, z<z_{b}$ で $\Lambda=\lambda$ である.ここ に, $z_{b}$ は河床位, $\lambda$ は土中の空隙率である. 浸透流 の運動方程式はダルシー則を用いた。透水係数は, 土質を等方的と見なすとともに，0.01 $\mathrm{m} / \mathrm{s}$ を空間的 に一様に与えた. 表面流の水深が河床材料の平均粒 径以下となったとき, 長田 ${ }^{13)}$ と同様に, 表面流の運 動方程式として, 圧力項と河床せん断力項のみを考 慮して表面流の計算を行った。表面流の河床近傍の 流速は, 水深平均流速の流線の曲率より予測し, 係 数值は Engelund ${ }^{14)}$ と同様の 7.0 を用いている. 流砂 量は芦田・道上式 ${ }^{15}$ により算出し, 芦田・江頭・劉
16) と同様に，河床の局所的な勾配が流砂ベクトルに 及ぼす影響を考慮している。粒度分布の計算は，交 換層の概念による平野の方法 ${ }^{177}$ を発展させ, 交換層 の下に遷移層を導入した芦田・江頭・劉 $\left.{ }^{18}\right)$ にるる方 法を用いた。交換層の厚さは，簡単のため, 最大粒 径と等しくしている. 局所的な河床勾配は, 永瀬・ 道上・檜谷 $\left.{ }^{19}\right)$ の研究を参考に, 安息角よりも小さく なるように補正している. 本解析では, 植生を考慮 する. 植生の侵入・成長・消滅および植生間の相互 作用等に関する条件は, 植生種や気象条件等により 大きく異なり非常に複雑なため, 数学モデルとして は十分に確立されていない，そこで，本研究では， 清水・辻本の研究 ${ }^{20)}$ を参考に, 流体抵抗として植生 を考慮するとともに, 植生の密生度の値を変化させ, 植生の侵入・成長・消滅過程を考慮する. 植生の密 生度は, 計算点が陸域となると, 最大值が 0.05 とな るように 0 から線形的に増加を始める.植生の消滅 については，河床低下による消滅を想定し，植生侵 入時よりも河床位が下がると植生が送流すると見 なして密生度を 0 とした. 植生域内の流砂量は有効 掃流力を用いて算出する.

計算領域は, 固定側岸を有した長さ $15 \mathrm{~m}$ の直線矩

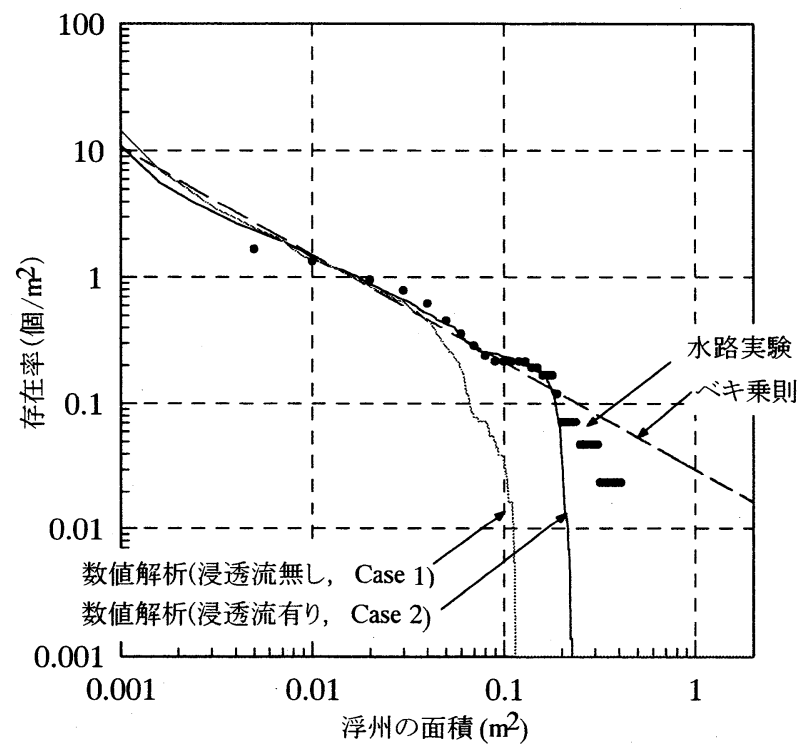

図 1 浮州の面積と浮州の存在率との関係（実験結果 は，文献 9)より引用）

表 1 数値解析に用いた水理条件

\begin{tabular}{|c|c|c|c|c|c|c|c|c|c|}
\hline & $\begin{array}{l}\text { 流量 } \\
(l / \mathbf{s})\end{array}$ & $\begin{array}{c}\text { 水路幅 } \\
\text { (m) }\end{array}$ & 河床材料 & $\begin{array}{l}\text { 水深 } \\
(\mathrm{mm})\end{array}$ & 川幅/水深 & $\begin{array}{l}\text { 無次元 } \\
\text { 掃流力 }\end{array}$ & 浸透流 & 給水条件 & 植生 \\
\hline Case 1 & 1.90 & 1.0 & 二様砂 & 65 & 155 & 0.041 & 考慮せず & 定常 & 考慮せず \\
\hline Case 2 & 1.90 & 1.0 & 一様砂 & 65 & 155 & 0.041 & 考慮 & 定常 & 考慮せず \\
\hline Case 3 & 0.76 & 0.4 & 混合砂 & 65 & 62 & 0.041 & 考慮 & 定常 & 考慮せず \\
\hline Case 4 & 1.90 & 1.0 & 混合砂 & 65 & 155 & 0.041 & 考慮 & 定常 & 考慮せず \\
\hline Case 5 & $0.06 \sim 1.46$ & 0.4 & 混合砂 & - & - & - & 考慮 & 非定常 & 考慮せず \\
\hline Case 6 & 3.80 & 2.0 & 混合砂 & 65 & 310 & 0.041 & 考慮 & 定常 & 考慮せず \\
\hline Case 7 & 3.80 & 2.0 & 混合砂 & 65 & 310 & 0.041 & 考慮 & 定常 & 考慮 \\
\hline Case 8 & 2.53 & 2.0 & 混合砂 & 58 & 342 & 0.032 & 考慮 & 定常 & 考慮 \\
\hline Case 9 & 2.53 & 1.33 & 混合砂 & 65 & 179 & 0.041 & 考慮 & 定常 & 考慮 \\
\hline Case 10 & 3.80 & 2.0 & 混合砂 & 65 & 310 & 0.041 & 考慮 & 定常 & 考慮 \\
\hline
\end{tabular}



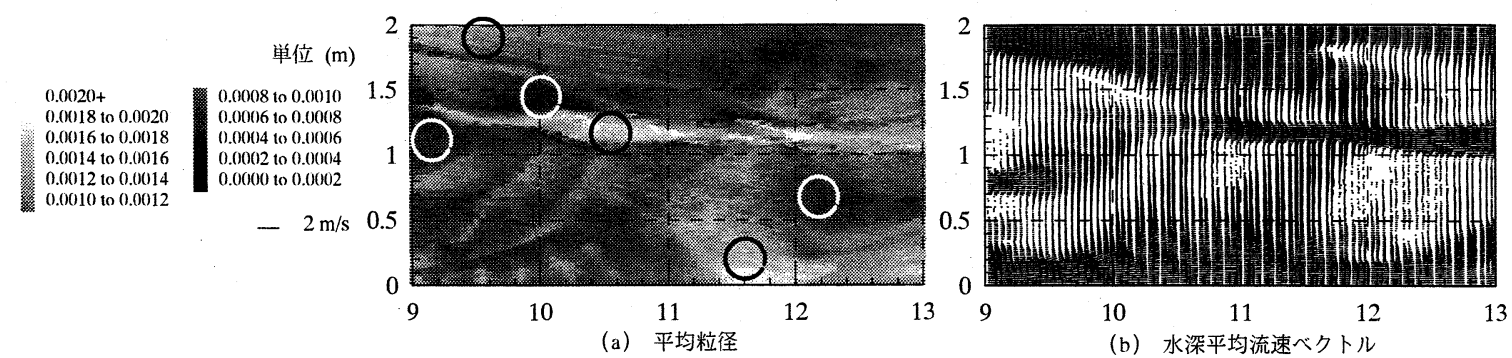

図 2 河床材料の平均粒径の空間分布（Case 6, 白丸が砂州上の細粒化，黒丸が流路内の粗粒化）

形断面水路を想定したものである。初期河床形状は 平坦床に平均粒径の $1 / 10$ スケールの振幅を有する 微少擾乱を計算区間全体に与えたものである。上流 境界における流砂量は，境界における水理量をもと に，掃流砂量式により算出されたものを与える．下 流端の河床は固定床とし，時間的に変化させない。 計算条件を表 1 に示す。河床勾配は $1 / 100$ で，土層 厚は $0.1 \mathrm{~m}$ とした.混合砂の標準偏差は 1.93 である. 竹林・江頭 ${ }^{12}$ によると, これらの条件は, 全て, 網 状流路の形成水理条件にある.

\section{3. 浸透流が浮州形状に与える影響}

浸透流の有無により, 流路の動態は変化する。こ こでは，特に顕著な影響が表れる浮州形状について， 検討する. 図 1 は浮州の面積と浮州の存在率との関 係を示したものである.ここで, 浮州の存在率とは， 当該面積以上の面積を有する浮州の単位面積あた りの数である.浸透流を考慮していない Case 1 では， 浮州のスケールが実験值よりもかなり小さいが, 浸 透流を考慮することにより, 面積の大きい浮州の存 在率が良く再現されていることがわかる。これは， 浮州への流れの侵入過程及び砂州上の水たまりの 形成機構の違いによるものである.つまり, 水路実 験では, 河床材料の透水性が非常に大きく, 浮州へ の水の流れは, 急速に浸透していく.しかし, Case 1 ではそれらが表面流として評価されるため, 浮州 面積が減少する.さらに, 網状流路内の流れは非定 常流となるため ${ }^{9}$, 流路内の水位の低下とともに, 砂州上に水たまりが形成される。これらも，水路実 験では急速に浸透していくが, Case 1 では水たまり のまま残る. また, 図 1 に示すように, 浮州の存在 率の分布はべキ乗則に従い, 自己アフィンフラクタ ルとなっていると考えられるため ${ }^{21)}$, 非常に小さな 空間スケールの流路が形成される。そのような小ス ケールの流路の形成には, 浸透流が大きく寄与する ものと考えられる.

\section{4. 河床材料の粒度の空間分布特性}

図 2 にCase 6 における河床材料の平均粒径の空間 分布を示す. 全体的には，河床位の高い領域で細粒 化, 河床位の低い領域で粗粒化であり, 流砂の輸送

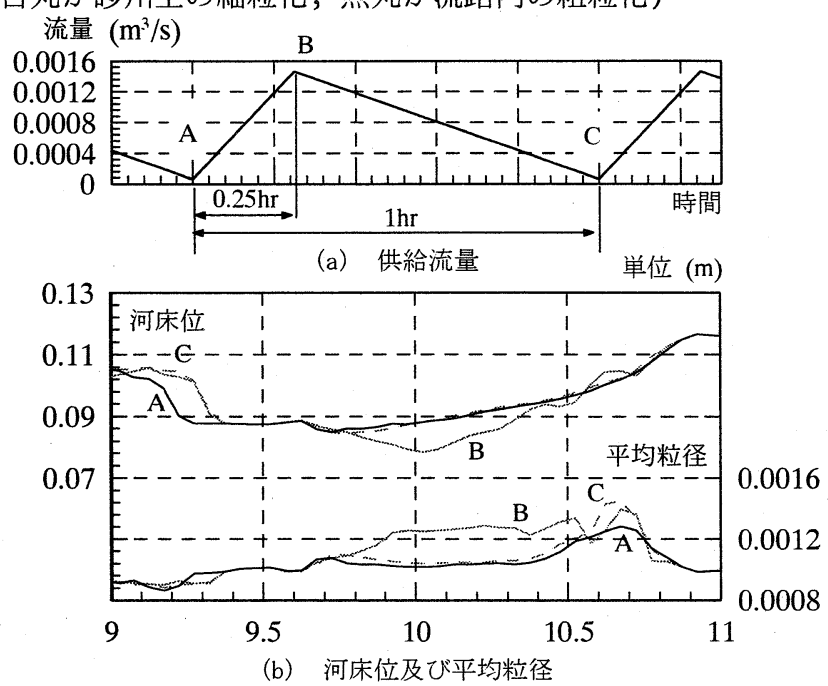

図 3 非定常給水条件における淵の河床位及び平均粒径 の時間変化 (Case 5)

特性に対応した分布となっている。つまり，流砂の 中に占める細粒分は粗粒分よりも多いため, 洗掘域 で粗粒化, 堆積域で細粒化が生じている。しかし, 網状流路の流路内の河床材料に関する現地調查 ${ }^{1), 22)}$ によると，淵で細粒化，瀬で粗粒化となっている。 このような現地調査と解析との違いは, 給水条件の 非定常性によるものと考えられる.図 3(b)は，図 3(a)で示す条件で上流端から給水を行った Case 5 の水路右岸沿いの河床位及び河床材料の平均粒径 の時間変化を示している。これによると, 淵におい て, 少流量時の河床位は高く平均粒径が小さいが, 大流量時には河床は洗掘され, 平均粒径が大きくな ることがわかる。一般的に，現地調查は平水時に行 われる。つまり, 現地調査で得られる淵の河床材料 は, 本解析で少流量時の河床材料に対応していると 考えられる。また，これらの結果は，平水時に測定 される定期横断測量による河床位よりも洪水時の 方が淵の河床位が洗掘されていることを示すとと もに, 洪水時の最大洗掘深は, 淵のボーリング調査 を行い, 河床材料の粒度の鉛直分布を調べることに よって, 得られる可能性を示している.

\section{5. 洪水ピーク流量の減少が流路の固定化及び 流路本数の減少に与える影響}

洪水ピーク流量の減少は, 砂州の冠水率を低下さ せ，植生が流れにより流送されにくくなるため，植 

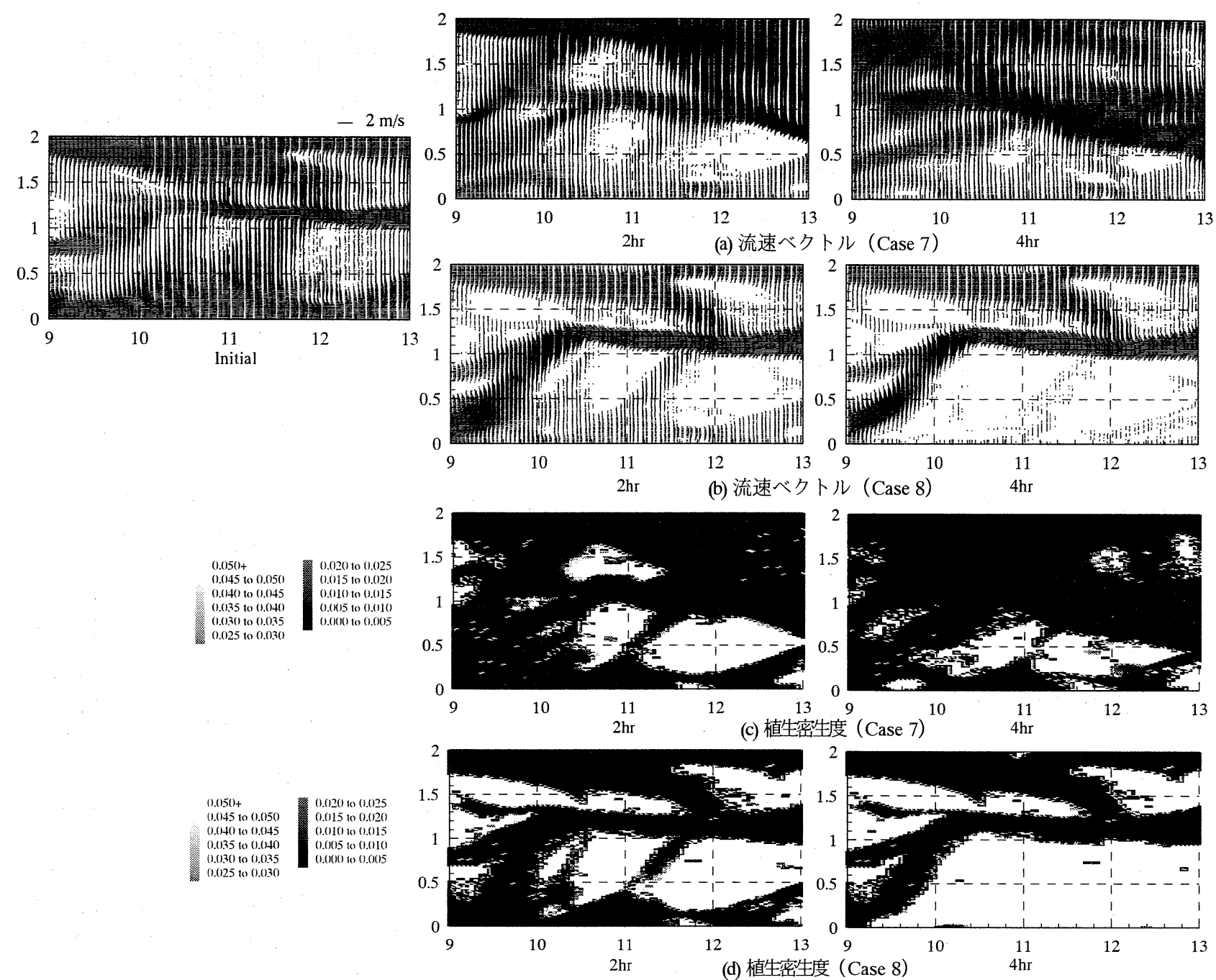

図 4 水深平均流速ベクトル及び植生密生度の時間変化（Case 7 と Case 8)

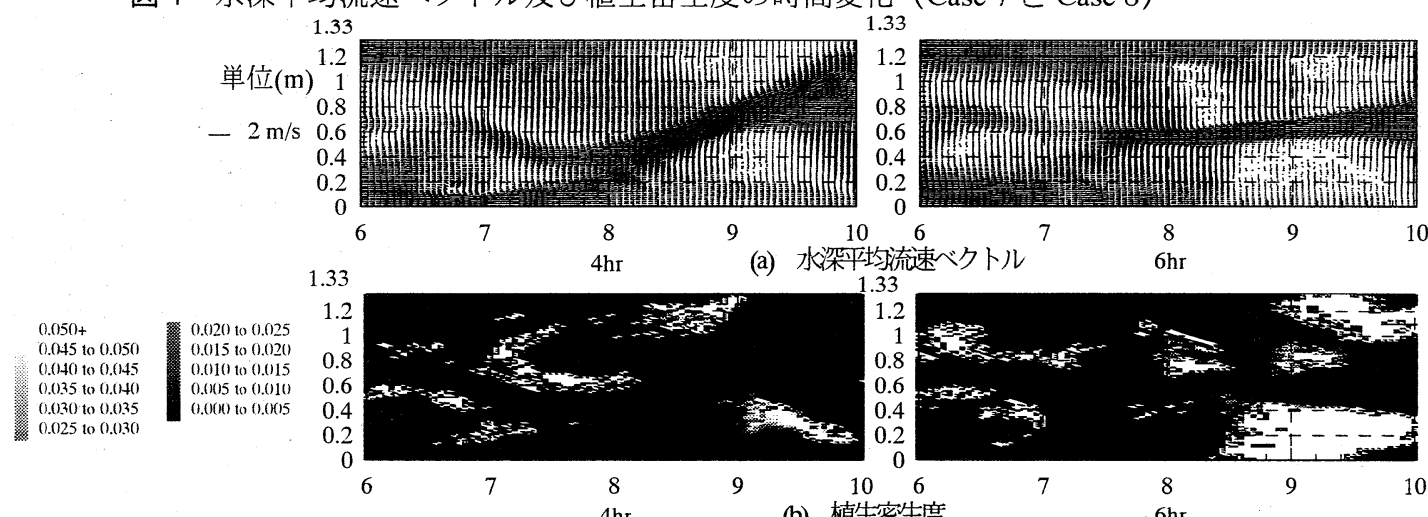

図 5 水深平均流速ベクトル及び植生密生度の時間変化（Case 9)

生の繁茂を促進する。さらに，植生は土砂を捕捉す るため，砂州上の流路の形成を抑制するとともに， 砂州の河床位を高めるため, 砂州の冠水率をさらに 低下させる。これらのメカニズムについては，現地 調査により，既に多くの知見が得られている ${ }^{23)}$ 。こ こでは，これらの現象を数值シミュレーションによ り再現するとともに，河道内の物理環境の多様性を 創生させる一つの方法を提案する。

図 4 は Case 7 と Case 8 の水深平均流速ベクトル 及び植生密生度の空間分布を示している.これら二 つの解析は，Case 6 の 2.5 時間後の解析結果を初期
条件としている。また, Case 8 の上流端供給流量は, Case 7 の流量の約 2/3 となっている。これによると， 流量を減少させていない Case 7では, 流路が時空間 的に変動するとともに，植生が成長・消滅を繰り返 しており，過剰な植生繁茂及び流路本数の減少は見 られない。一方，流量を減少させた Case 8 では，砂 州上の植生が発達するとともに, 流路本数が減少し て比較的空間スケールの大きい流路に統合されて いることがわかる。さらに，空間スケールの大きい 流路は, 初期状態からほとんど位置を変化させてい ないことがわかる。また，流れが流路内へ集中し， 

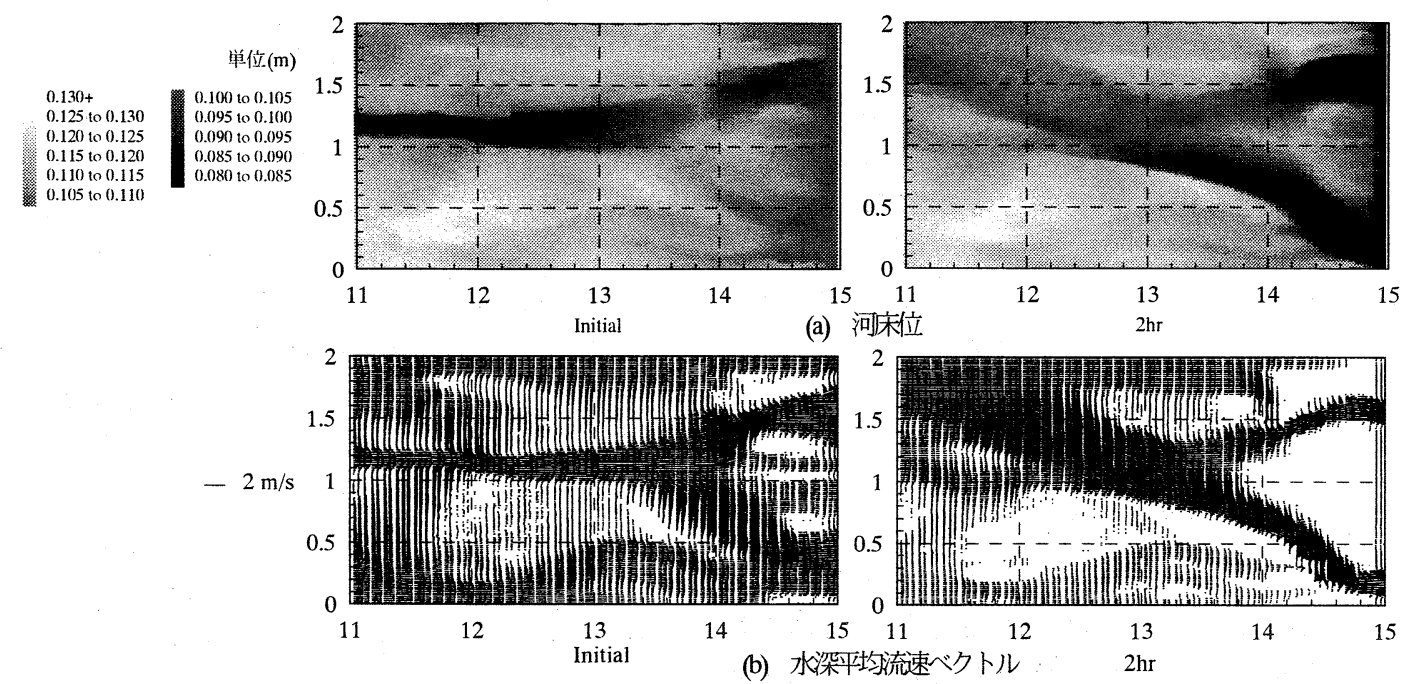

図 7 下流端河床位低下による流路本数の減少過程 (Case10)

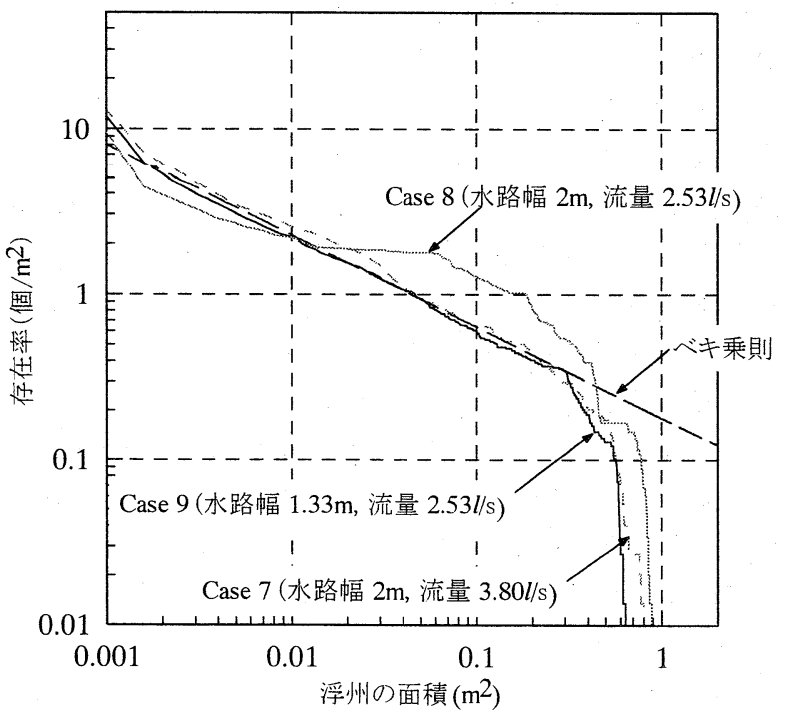

図 6 浮州の面積と浮州の存在率との関係（Case 7, Case 8, Case 9)

陸水の遷移域が減少していることがわかる。現在の 日本の多くの河川は，ダムによる洪水調節により， Case 8 のような状態となっていると考えられる。こ のような河川に河道内の物理環境の多様性を創生 させる一つの方法としては，川幅・水深比を適当に 調節するということが考えられる。

図 5 は Case 8 に対して, 流量をそのままとし, 水 路幅を狭めた Case 9 の水深平均流速べクトル及び 植生密生度の空間分布の時間変化を示している。こ れによると, 流路の時空間的な変化が復活するとと もに, 植生の成長・消滅が繰り返し発生しているこ とがわかる. 図 6 は浮州の面積と浮州の存在率との 関係を示したものである。これによると, Case 8で は, 流量の減少により最大スケールの浮州が大きく なるとともに, 面積の大きい浮州の数が増え, 逆に 面積の小さい浮州が減少したため，分布の勾配が緩 やかとなり，場の多様性が失われていることがわか る.また，面積が $0.5 \mathrm{~m}^{2}$ 付近で分布が不連続となっ ているのは, 流路統合の結果, $0.5 \mathrm{~m}^{2}$ 程度の浮州の
みが残されたためであり，これも場の多様性が失わ れたことを示すものである。しかし，Case 9 を見る と，水路幅を狭めることにより，Case 7 の分布と同 一の勾配に戻り，河道内の物理漴境の多様性が創生 されていることがわかる。これらの結果は，ダムに よる洪水調節及び土地利用形態などの水と土砂の 流出特性が変化しても, 川幅・水深比を適切に設定 すれば多様な水辺空間を創生できることを示す.た だし，川幅を狭めたため，浮州の最大スケールは小 さくなり，このスケールの物理環境を利用していた 動植物は生息できなくなると考えられる。ここで川 幅とは，網流させる領域の幅であり，必ずしも堤防 間距離ではなく，低水路幅を想定できる場もある。

\section{6. 下流域の河床低下が流路の固定化及び流路 本数の減少に与える影響}

日本の多くの河川は, 最近 50 年間で流路内の河 床位が著しく低下している。これについては，5.で 検討した洪水ピーク流量の減少も砂州での植生繁 茂により流路の幅・水深比が減少するので一つの原 因となり得るが，ダム貯水池及び砂防ダムへの堆砂 による土砂供給量の減少, 砂利採取及び河積確保を 目的とした河床掘削等が主要因と考えられる。これ らの内, 下流域の河床低下は, 砂利採取及び河積確 保を目的とした河床掘削によるところが大きいと 考えられる。ここでは, 河床掘削が流路の固定化及 び流路本数の減少に与える影響を検討する。

図 7 は Case 10 の河床位, 水深平均流速ベクトル の空間分布の時間変化を示している. Case 10 は, Case 6 の 2.5 時間後の解析結果を初期条件としてい る。ただし, 解析領域最下流端の河床位を 90 秒か けて線形的に $0.05 \mathrm{~m}$ 低下させ, その後, 低下させた 河床位をそのまま保っている。これによると, 砂州 域の河床はほとんど低下しておらず，河床低下は流 路内で主に発生しており, 流れが比較的空間スケ一 
ルの大きい流路に集中していくことがわかる.さら に，比較的空間スケールの大きい流路の位置は，時 間的にほとんど変化していないことがわかる.

これらの結果は, 短期間で埋め戻されないような 大規模な河床掘削は, 主流路内の河床低下を促進し， 砂州上の冠水率を低下させるため, 流路の固定化及 び流路本数の減少を促進することを示す。

\section{7. 結論}

本論文では, 数值解析により, 混合砂河床の網状 流路の動態及び河床材料の粒度の空間分布特性を 明らかにするとともに, 砂州の固定化及び流路本数 の減少機構を検討した. 本研究で得られた結果をま とめると以下のようになる.

(1) 網状流路では, 浮州が形成されるとともに, 自 然と流れが非定常となるため，浸透流を考慮し た解析が有効である。

(2) 定常流では, 流路内で河床材料は粗粒化し, 砂 州上で細粒化する。しかし，非定常流では，大 流量時に淵の河床が洗掘されるとともに河床材 料は粗粒化し，低流量時に淵で埋め戻しが発生 して河床材料は細粒化する。

（3）洪水ピーク流量の減少は, 砂州の冠水率を低下 させ植生の成長を促進するため, 流路の固定化 及び流路本数の減少に寄与する．このような河 道は，川幅を適切に設定することにより物理環 境の多様性を創生することが可能である.

(4) 短期間で埋め戻されないような大規模な河床掘 削は, 主流路内の河床低下を促進し, 砂州上の 冠水率を低下させるため, 流路の固定化及び流 路本数の減少を促進する.

謝辞 : 本研究は, 平成 14 年度科学研究費補助金若 手研究 (B)（研究代表者: 竹林洋史）の助成を受 けて行われた。記して謝意を表します。

\section{参考文献}

1) P. J. Ashworth, R. I. Ferguson, P.E. Ashmore, C. Paola, D. M.

Powell and K. L. Prestegaard : Measurements in a Braided River Chute and Lobe 2. Sorting of Bed Load During Entrainment, Transport, and Deposition, Water Resources Research, Vol. 28, No. 7, pp. 1887-1896, 1992.

2) Thome, C. R., Russell, A. P. G. and Alam, M. K. : Planform pattem and channel evolution of the Brahmaputra River, Bangladesh, Braided Rivers, The Geological Society, pp.257-276, 1993.

3) 藤田裕一郎, 赤松英樹, 村本嘉雄: 網状流路の形成過 程, 水工学論文集, 第 31 巻, pp.695-700, 1987.

4) 芦田和男, 江頭進治, 里深好文: 網状流路における流 砂量, 水工学論文集, 第 35 巻, pp.391-396, 1991.

5) 道上正規, 藤田正治, 日下部重幸: 水みちの発生・発 達過程の実験とシミュレーション, 水工学論文集, 第
39 巻, pp.613-618, 1995.

6) S. Egashira and H. Takebayashi : Self-formed low water channel in straight channel, Poc. IAHR Symposium on River, Coastal and Estuarine Morphodynamicspp. 509-518, 1999.

7) T. Takahashi and Y. Satofuka : Simulation model for channel variation in braided channel reach, , Proceedings of 12th Congress of the APD-IAHR, pp.45-54, 2000.

8) 倉林弘志, 清水康行: 浮州の形成を考慮した網状流路 における河床変動解析, 水工学論文集, 第 46 巻, pp.743-748, 2002.

9) 竹林洋史, 江頭進治, 岡部健士 : 網状流路の時空間的 な変動特性, 水工学論文集, 第 46 巻, pp.737-742, 2002.

10) 例えば, Takebayashi, H., Egashira S. and H. S. Jin : Numerical simulation of alternate har formation, River Sedimentation, pp.733-738, 1998.

11) 須賀堯三 : 河川における蛇行のモード変化, 第 37 回 土木学会年次学術講演会講演概要集, II -292, pp. 583-584, 1982.

12) 竹林洋史, 江頭進治 : 自己形成流路の形成過程と形成水 理条件, 土木学会論文集, Vol. 677 No.II-55, pp. 75-86, 2001.

13) 長田信寿 : 一般座標系を用いた平面 2 次元非定常流 流れの数值解析, 水工学における計算機利用の講演会 講義集, 土木学会, pp. 51-76, 1999.

14) Engelund, F.:Flow and Bed Topogaphy in Channel Bends, Jour. of Hy. Div. ASCE, Vol. 100, No. HY11, 1974.

15) 芦田和男, 道上正規 : 移動床流れの抵抗と掃流砂量 に関する基礎的研究, 土木学会論文報告集, 第 206 号, pp.59-69, 1972.

16) 芦田和男, 江頭進治, 劉炳義 : 蛇行流路における流 砂の分級および河床変動に関する数值解析, 水工学論 文集, 第 35 巻, pp.383-390, 1991.

17) 平野宗夫:Armoring をともなう河床低下について, 土 木学会論文報告集，第 195 号, pp. 55-65, 1971.

18）芦田和男, 江頭進治, 劉炳義 : 二層モデルによる複 断面河道の流れ及び河床変動の数值解析, 京都大学防 災研究所年報, 第 35 号, B-2, pp.41-62, 1992.

19) 永瀬恭一, 道上正規, 檜谷治: 狭窄部を持つ山地河川の 河床変動計算, 水工学論文集, 第 40 巻, pp.887-892, 1996.

20）清水義彦，辻本哲郎：植生帯を伴う流れ場の平面 2 次元解析, 水工学論文集, 第 39 巻, pp.513-518, 1995.

21) Sapozhnikov, V. B. and E. Foufoula-Georgiou : Self-affinity in braided rivers, Water Resources Research, 32, pp. 1429-1439, 1996.

22) 江頭進治, 金海生, 竹林洋史, 池田晶, 永田徹 : 木 津川下流域の河床変動と土砂収支, 水工学論文集, 第 44 巻, pp. 777-782, 2000.

23) 例えば, 清水義彦, 小葉竹重機, 岡田理志: ハリエ ンジュによる動的河道内樹林化について, 水工学論文 集, 第 45 巻, pp.1099-1104, 2001.

(2002. 9. 30受付) 